\title{
APPLYING FLIPPED LEARNING APPROACH IN EFL CLASSROOM IN LIEPAJA CENTRE PRIMARY SCHOOL
}

\author{
Kristine Bārdule \\ Liepaja University, Latvia
}

\begin{abstract}
Educational planning documents highlight the importance of differentiation of the learning process and improving individuals' competencies to fulfil complex tasks. By a flipped learning approach, when the students acquire the new information at home, watching the instructional video, more time is devoted to the active learning process in the classroom, as a result of which the students have the opportunity to improve their competencies.

Within this article's framework, a case study's data on using a flipped learning approach in teaching elementary school students are analysed. The study included fourteen 4th grade English as first foreign language students of Liepaja Centre primary school. The study was conducted in 2020 from 30 October till 27 November.

The study's main objective is to analyse possibilities to differentiate the learning process according to students' individual needs and improve competencies using a flipped learning approach.

The study found that teachers have an excellent opportunity to give students individual and useful feedback and differentiate students' work according to their individual needs. The study revealed that students have the possibility to improve competencies.

It is useful to introduce teachers to the possibilities of a flipped learning approach to individualize the learning process and develop students' competencies as it is stated in education planning documents.
\end{abstract}

Keywords: competences, differentiation, elementary EFL classroom, feedback, individualization.

\section{Introduction}

The National Planning Document "Guidelines for the Development of Education" determines that education must meet the needs and opportunities of the individual both by providing an inclusive approach to teaching and by supporting the promotion of talent and excellence; measuring the growth progress of an individual; opportunities to plan individual learning and self-development paths; as well as the active use of technology in providing these individualized solutions (Ministry of Education and Science, 2020). Individualization of the learning process and differentiation in a class with many students is problematic for the teacher. Bergamann and Sams point that "Personalization is truly 
overwhelming for most educators, and they end up taking the shotgun approach to teaching: present as much content as they can in the time they have and hope that it hits as many students as possible-and sticks" (Bergmann \& Sams, 2012) According to the flipped learning approach, organizing the learning process solves this problem because this type of learning is suitable for students with different levels of ability (Girmen \& Kaya, 2019). "Flipping the classroom establishes a framework that ensures students receive a personalized education tailored to their individual needs" (Bergmann \& Sams, 2012). There is a possibility to differentiate tasks, time, support for students at homework (Bergamann \& Sams, 2015) and in the classroom according to students' abilities. Qualitative differentiation and individualization of work are implemented, where more able students have to show an understanding of a more profound topic; in turn, students with learning difficulties learn the most important aspects of the subject. There is a balance between online and face-to-face learning. In face-to-face classes, it is possible to work with students individually and provide additional explanations to those who have not experienced the topic (Bergamann \& Sams, 2012).

To successfully implement the flipped learning approach, the teacher must use backward planning step by step from subject standard and program to homework activities. Now there's a much broader understanding that the in-class activities need to be designed first (McKenzie, 2018) to set outcomes to be achieved in a particular lesson.

The study's main objective is to analyse the possibilities of differentiation the learning process according to students' individual needs and abilities, providing meaningful feedback, and developing competencies using the flipped learning approach. There are analysed Latvia's education planning documents, scientific literature on the flipped learning approach, and data of a case study of English as the first foreign language in 4th grade.

\section{Literature Review}

"Flipped learning is a framework that enables educators to reach every student. The Flipped approach inverts the traditional classroom model by introducing course concepts before class, allowing educators to use class time to guide each student through active, practical, innovative applications of the course principles" (Flipped Learning Global Initiative). A flipped learning model has two components: direct instruction using video lectures outside the classroom to acquire knowledge, and active face-to-face learning inside the classroom (Ansori \& Nafi, 2017). Flipped learning modifies the traditional learning environment - in this model, the teacher is not the main one in the classroom who provides his/her knowledge to the students, but a student-cantered learning process is organized, in which the teacher is a leader, assistant, mentor, coach. 
Students learn the topic individually outside the classroom as homework by watching video (Binit Halili, Hijja, Rabihah, Sulaiman, \& Razaket, 2019; Marqués-Molías, Palau-Martín, Usart, \& Morilla, 2019; Yoshida, 2019) and get acquainted with the information prepared by the teacher. During such homework, the students can control his/her learning through pause, repetition. The students perform the work at the place, time, and pace of his/her choice (Lee \& Lai, 2017; Binit Halili et al., 2019; Jackson, 2019; Marqués-Molías et al., 2019; Mohammadi, Barati, \& Youhanaee, 2019; Muntean, 2019; Tomas, Evans, Doyle, \& Skamp, 2019; Yoshida, 2019; Zou, 2020), according to interests, abilities, and learning style (Yean, 2019). Being able to watch the video again, pause it, rewind the recording helps to better understand it, and allows students to get an idea of the next lesson's topic, thus better preparing for it (Yoshida, 2019; Muntean, 2020). Research also shows that students who do tasks while watching videos are better prepared for classroom work (McKenzie, 2018). By watching videos and completing assignments before class, students are willing to become more actively involved in classroom work, share opinions, and interact with each other (Abdullah, Hussin, \& Ismail, 2019). Students have an idea of the topic's content, have acquired basic knowledge, ask questions about what is not understood (Zamora-Polo, Corrales-Serrano, Sánchez-Martín, \& Espejo-Antúnez, 2019), and the teacher has the opportunity to address their misconceptions before they come to long-term memory (Bergmann \& Sams, 2012).

Table 1 Traditional and Flipped Learning Process

\begin{tabular}{|l|l|l|l|}
\hline \multicolumn{2}{|c|}{ Traditional learning process } & \multicolumn{2}{c|}{ Flipped learning process } \\
\hline \multicolumn{1}{|c|}{ Activity } & Time & \multicolumn{1}{c|}{ Activity } & Time \\
\hline Warm-up-activity & $5 \%$ & Warm-up-activity & $5 \%$ \\
\hline Go over homework & $20 \%$ & Question and answer time on video & $10 \%$ \\
\hline Lecture new content & $35 \%$ & Guided and independent practice & $85 \%$ \\
\hline Guided and independent practice & $40 \%$ & & \\
\hline
\end{tabular}

The classroom environment is formed as a dynamic, interactive learning setting, in which a more in-depth acquisition and understanding of the study content takes place with the help of a teacher and in cooperation with classmates. The teacher manages students who work in groups, actively cooperate, apply the acquired knowledge, skills, and engage in creative activities. Students are actively involved in the learning process and developing higher thinking skills (Bergmann \& Sams, 2012). According to the flipped learning model, students receive personalized support appropriate to their needs. The teacher has the opportunity to work individually with students who need additional help during the lesson. As a result of class discussions and individual support, students improve their social skills and achievements (Bergman \& Sams, 2015). The 
founders of flipped learning, Bergamann \& Sams (2012), compared traditional and flipped learning (Table 1). In the flipped learning process, it is possible to plan more time for students' active learning in the classroom.

Classroom activities in flipped learning process begin with a test of students' understanding of the topic learned at home. At the beginning of the lesson, students have the opportunity to ask questions about a theory they have not understood. Students answer the teacher's questions thus demonstrate understanding (Binit Halili et al., 2019), take a digital test (Yoshida, 2019; Muntean, 2019), or discuss video watched at home, so the teacher can assess what the students have not understood and answer to students' questions (Mohammadi et al., 2019; Zamora-Polo et al., 2019). Thus, students have the opportunity to listen to the opinions of others, ask questions, discuss, eliminate misunderstandings, and mistakes at an early stage (Marqués-Molías et al., 2019). By evaluating the students' answers, the teacher can give the students meaningful feedback about their performance and an overview of the topic learned at home, emphasizing the most essential information (Muntean, 2019).

Most lesson time is devoted to practical activities - skills development and improvement of learning strategies (Marqués-Molías et al., 2019). Valuable lesson time is used productively. There is no need to write down information and instructions (Gonzales, 2019). As students have already gained information by watching videos at home, they have knowledge of a topic that is strengthened, expanded, applied in non-standard situations during the class time. During the lesson, large classes are transformed into interactive study groups. Students participate in competitions, discussions, co-operate, as a result of which students have the opportunity to communicate more with classmates on language subjects, thus practicing speaking skills and improving language competence (Zou, 2020), read books, write descriptions (Bergmann \& Sams, 2015). The flipped learning allows students to be more active in the classroom and gives them more opportunities to develop academic language skills and confidence in language use (Ansori \& Nafi, 2017). Students address problem-solving issues to deepen their understanding of the topic, thus developing critical thinking skills (Zamora-Polo et al., 2019; Kurnianto, Wiyanto, \& Haryani, 2020). Students recall, apply, and expand the knowledge they have acquired before class (Tomas et al., 2019), complete tasksin books and worksheets, correct mistakes in pairs, practice concepts (Ansori \& Nafi, 2017; Mohammadi et al., 2019; Muntean, 2019), conduct experiments, prepare presentations, engage in brainstorming on a topic, and answer questions asked by a teacher (Lee \& Lai, 2017; Yean, 2019). If necessary, students can re-watch the video to clarify the information and discuss it with the teacher (Binit Halili et al., 2019). During the lesson, students create materials that show a deeper understanding of the topic. - videos, podcasts, websites, blogs, which may include tutorials, strategies. The time devoted to 
practical activities in the lesson is sufficient for students to perform useful tasks, demonstrate the acquired skills and present their work (Lee \& Lai, 2017). Thus, a student-centred learning process is implemented to collaborate with each other; it is an opportunity to provide deep-learning to develop 21st-century competencies (Lee \& Lai, 2017; Gonzales, 2019).

The teacher is not a provider of information but collaborates with students to advise and guide students to help those who need it most (Bergmann \& Sams, 2012; Ansori \& Nafi, 2017). The teacher is a mentor who observes the process from the outside, encourages students to work independently, provides individual help (Jackson, 2019), answers questions, decrease misunderstandings individually (Tomas et al., 2019), provides students with support in applying practical knowledge, teaches learning strategies and explain higher-difficulty tasks (Muntean, 2020), provide feedback (Mohammadi et al., 2019). Thus, learning becomes interactive and effective (Gonzales, 2019). Students receive the necessary advice, support, growth-oriented, personalized feedback (Yean, 2019; Zou, 2020), and encouragement to engage in active learning and group discussions, asking and answering questions, resulting in improved studentstudent and student-teacher interaction (Binit Halili et al., 2019).

At the end of the lesson, the works created by students are reviewed and discussed (Tomas et al., 2019), game-based activities are implemented according to the content to be learned (Zamora-Polo et al., 2019), conclusions are made about what has been done (Yoshida, 2019). Students are informed about preparation for the upcoming lesson or task (Yean, 2019) and about the learning materials' availability to be learned at home (Muntean, 2019).

\section{Research Methodology}

The case study was conducted in cooperation with English as a foreign language teacher who is open-minded, interested in new pedagogical practices, wants to improve her work, and has 30 years of work experience.

One group (14 students) of 4th grade English class students (6 boys and 8 girls) was chosen to reach the aim - analyse possibilities of the differentiation of the learning process according to students' individual needs and possibilities to improve competencies using a flipped learning approach. Students have access to technology and the Internet at home and have equal knowledge of English. Two students have an average English level, ten students have an optimal English level, and two students have a high English level. Students learn English as the first foreign language from the 1st grade. In the 4th grade, students have 3 English classes per week, where two classes are together and contain 80 minutes, and one is 40 minutes. To reach the aim of the research, the case study was chosen as a design in order to observe the process of differentiation and competencies 
development in details and encouraging teachers to make changes in their pedagogical practice (Thomas, 2021).

A literature review was done on a flipped learning to develop theoretical understanding and formulate ideas about the study's object in a preparation phase. The teacher prepared lesson plans and practical tasks for each topic. Before implementing the flipped learning approach, the teacher informed the students about changes in the learning process organization. She taught them possibilities of video-pausing, re-watching the video or its part, and taking notes. Suitable methods for the case study were chosen - observing and recording of the lessons, transcribing the students' and teacher's activities, and comparing students' performance at the beginning and end of each class and in two tests - on the topic learned using the traditional approach and test after using flipped learning approach. A questionnaire was developed, which the students filled in at the end of the case study to discover the students' opinions about organizing lessons according to flipped learning principles. In a structured interview, the teacher expressed her views on the flipped learning approach's benefits and restrictions.

The action phase was conducted from October 30, 2020, till November 27, 2020, to test out ideas based on literature review. A total of 8 lessons were observed. During the first lesson (October 30 ), the case study was validated. The case study is based on seven lessons observation results, two of which were 80minute classes and three 40-minute classes. The case study was started on November 10, as students began learning a new topic, "A very special day!". Students acquired reading, speaking, listening, writing skills, and grammar within each topic. Within this topic's framework, the students learned demonstrative pronouns, cardinal and ordinal numbers in the amount of 100, and dates.

In the assessment phase were analysed the teaching-learning process results, students' test results, questionnaires, and interview. Findings of positive aspects and difficulties necessary to take into account were clarified, and conclusions on implementing flipped learning approach in other classes were written.

\section{Research Results}

Before each class, the students in the information system e-class got informed with the teacher's prepared materials on the topic in a presentation, memo, and/or video material available on YouTube (2018), which corresponds to the English textbook Welcome 2 used at school (Unit 4 Lesson 1, Lesson 2, Lesson 3). Students took notes at home - wrote the new words in their dictionary, wrote down the sentences according to the spelling/word order, wrote down the conclusions about the spelling based on the researched material.

At the beginning of the lesson, students answered the teacher's questions and discussed topics acquired at home in pairs or groups. Under the teacher's 
guidance, students drew conclusions about the unclear issues that should be clarified during the lesson. The teacher involved the students in setting goals and planning the class activities to improve their knowledge and skills.

The teacher used a test on quizziz.com to determine the students' understanding of the topic learned at home (Table 3), thus gaining an insight into the students' knowledge of the subject. The class time was allocated for the application and strengthening of the knowledge acquired at home, improving skills, and developing learning strategies. During the classes, the students recall what they had learned at home, applied their knowledge and skills, learned the topic in-depth, working individually, in pairs, and in groups. Students carried out practical tasks in a workbook, worksheets and demonstrated the skills they had acquired by playing didactic games, using the website learningapps.org and working on interactive live worksheets. Students engaged in discussions to implement the tasks, collaborated, presented and explained their views, taught the topic to classmates, corrected mistakes during class time. So, students improved language competence, speaking skills, cooperation skills, and critical thinking skills. The student-centred learning process was implemented, in which students learned in-depth and developed 21st-century competencies.

During the teaching process, the teacher listened to the students' discussions, led the learning, collaborated with the students, encouraged and counselled them. The teacher answered the unclear issues, eliminated misunderstandings and mistakes, explained the misunderstanding individually. The teacher provided feedback to the groups, individual assistance to students who needed it, and personal feedback indicating improvement opportunities. As a result, students became more actively involved in teaching, cooperated more safely and confidently with classmates. The teacher prepared tasks for students with different levels of English language skills. Students with a high level of English language skills were offered higher-level tasks. Students with average English language skills were offered reminders, samples, and lower-level tasks.

Table 2 Differentiation of the Learning Process

\begin{tabular}{|l|l|l|}
\hline & \multicolumn{1}{|c|}{ Lower-level } & \multicolumn{1}{|c|}{ Higher-level } \\
\hline Content & $\begin{array}{l}\text { Writes full dozens } \\
\text { Connect the number to its written } \\
\text { notation }\end{array}$ & $\begin{array}{l}\text { Writes various two-digit numbers } \\
\text { Write a number with words } \\
\text { Write full sentences }\end{array}$ \\
\hline Process & $\begin{array}{l}\text { Use a memo/sample } \\
\text { Classmates' help } \\
\text { Teacher's help }\end{array}$ & $\begin{array}{l}\text { Works independently } \\
\text { Examine tasks in pairs and groups, } \\
\text { discuss differences, prove their opinion }\end{array}$ \\
\hline Result & $\begin{array}{l}\text { The date is written with numbers } \\
\text { 3 sentences are written } \\
\text { Basic skills tasks are performed }\end{array}$ & $\begin{array}{l}\text { The date is written in words } \\
\text { 6 sentences are written } \\
\text { Additional tasks are performed }\end{array}$ \\
\hline
\end{tabular}


The teacher differentiated the content, process, and final product according to students' abilities (Table 2).

At the end of each lesson, students did the test in quizzis.com, showing the knowledge and skills they had acquired in the class. The students took the test in writing, indicating part of the goal to be achieved, which is related to grammar comprehension (Table 3). The teacher summarized what was learned in the lesson and invited the students to draw conclusions about the acquired knowledge, skills, and necessary improvement.

Table 3 Pre and Post-test Achievements

\begin{tabular}{|l|c|c|}
\hline \multicolumn{1}{|c|}{ Goal of the lesson } & $\begin{array}{c}\text { correct answers at } \\
\text { the beginning of } \\
\text { the lesson }\end{array}$ & $\begin{array}{c}\text { correct answers } \\
\text { at the end of the } \\
\text { lesson }\end{array}$ \\
\hline $\begin{array}{l}\text { I can write dozens in words; I can use them in a } \\
\text { dialogue. }\end{array}$ & $71 \%$ & $88 \%$ \\
\hline $\begin{array}{l}\text { I can write sentences with this/that these/those; I } \\
\text { can use this/that these/those in dialogues. }\end{array}$ & $30 \%$ & $85 \%$ \\
\hline $\begin{array}{l}\text { I can write ordinal numbers 1-10 in words; I can } \\
\text { use them in conversation. }\end{array}$ & $67 \%$ & $78 \%$ \\
\hline $\begin{array}{l}\text { I can write ordinal numbers 11-100 in words; I } \\
\text { can use them in conversation. }\end{array}$ & $32 \%$ & $48 \%$ \\
\hline $\begin{array}{l}\text { I can write dates independently, ask and answer } \\
\text { questions using ordinal numbers. }\end{array}$ & $67 \%$ & $85 \%$ \\
\hline
\end{tabular}

Pre-test results show that students have become familiarized with the topic at home and understood it. The test results reflect the positive dynamics of student performance at the end of all lessons.

By summarizing the activities observed in the classes, the average time allocated for each activity was calculated. Greetings and specification of the lesson's aim took on average $4 \%$ of the class time. On average, $14 \%$ of class time was spent asking and answering questions to limit misconceptions. On average, $82 \%$ of the class time was devoted to students guided and independent practice.

Students' answers in the questionnaire on the flipped learning process organization show that $100 \%$ of students get acquainted with the information sent by the teacher and performed the tasks before class as homework. $54 \%$ of students' re-view video after the lesson. $100 \%$ of students answered that the teacher's prepared video material/presentation/memo helped to better understand the subject. 


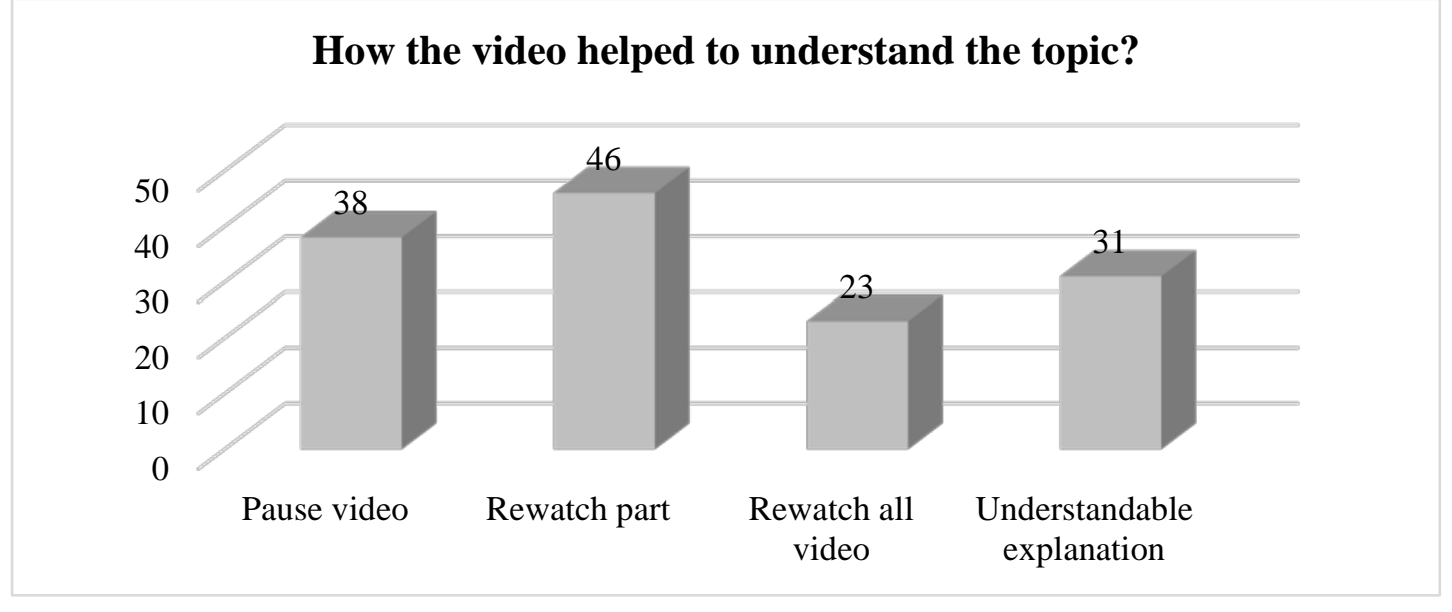

Figure 1 Ways of Using Video at Home

Students used the video material possibilities in various ways to better master the topic (Fig. 1). Three girls used several video materials options, pausing and re-watching a fragment or the whole video. Two of the students have a high level of English, one has an average level of English. 6students (46\%) re-watched a part of the video that they did not understand when watching it for the first time. 5students (38\%) used the opportunity to pause the video and take notes. 4 students (31\%) stated that they understood the topic because the video material was clear, simple, and understandable. 3students (23\%) watched the video several times to better understand the subject.

Using a Likert scale (fully disagree, disagree, neither agree nor disagree, agree, fully agree), students assessed the impact of flipped learning approach on their learning by evaluating 7 statements. 10 students (77\%) agree and fully agree that they understood the topic better if they looked at it before class. 10 students (77\%) agree and fully agree that they work more actively in the classroom if they obtained information at home.10 students (77\%) agree and fully agree that they are more confident and able to do well in English if they get familiar with a topic before class. 11 students (85\%) agree and fully agree that they like working in a group. 12 students (92\%)agree and fully agree that they like to do tasks on tablets in the classroom. 7 students (54\%) agree and strongly agree that they like explain the topic to classmates, and 7 students (54\%) agree and fully agree that they like their classmates explain the subject to them.

Comparing the students' achievement in two tests can conclude that the students' assessment in the second test, which was performed after the organization of the study process according to the flipped learning approach, is 0.43 points higher (7.07 and 7.5). In the first test, two students had grades 3 (below average), while in the second test, the lowest grade was 5 (average). 
Interview with the teacher identified the most significant difficulties in organizing the flipped learning process. In the planning process, it was challenging to plan and restructure the teaching materials and select a suitable video piece. It was time-consuming to formulate useful homework tasks and prepare various tasks corresponding to different ability levels to proceed with deep-learning. It was challenging to prepare individual, pair, and group work tasks to develop students' cooperation, planning, critical thinking, and self-directed learning skills. In the teaching process, difficulties appear when groups of students who did their job faster had to wait for feedback from the teacher if she provided feedback to another group. A slow internet connection made the learning process more difficult with tablets, and valuable classroom time was lost.

The teacher analysed her and students' work after each lesson, based on which tasks were set to solve problems. In planning - the lesson plan with small changes and material prepared once can be used repeatedly for an identical class and teaching a topic in the next school year. In the management of the lesson, to make the learning process run smoothly teacher prepared a descriptive plan of tasks for students to use, designed answer sheets for students' self-evaluation, and formed heterogeneous groups, where one of the students played the teacher's assistant role.

As positive aspects, the teacher emphasized the possibility for students to practice more, collaborate, work in pairs and groups, receive support from the teacher and classmates as a result of which the students learned from each other. The teacher noticed the students' active involvement in the learning process as important because the students had become acquainted with the topic at home, as a result of which they asked questions about the issue and expressed their opinions and conclusions. Students developed cooperation, critical thinking, problemsolving, and self-directed learning skills. Students, working in pairs and groups, explained the issue, compared their performance, explained their opinion to the teacher and classmates, reflected on their learning, set goals for further work to improve knowledge and skills. By using ICT in the learning process, students developed a deeper understanding of technology's various uses for learning purposes.

\section{Conclusions}

Flipped learning is a teaching approach that allows the teacher to use lesson time to engage students in active learning, enable the teacher to individualize learning according to students' abilities; the students better understand the content of the topic and work more successfully in the lesson.

The case study results showed that it is possible to differentiate learning processes better. The use of the flipped learning approach has a positive effect on 
students' performance. This approach allows students to engage in an active learning process, deepen knowledge-develop cognitive skills, improve transversal skills-social and emotional skills-cooperation at different levels (communicate, express and explain their opinions), critical thinking, problem-solving, and selfdirected learning (goal setting, planning, learning management). These are competencies that students need to develop in the learning process according to the curriculum.

The students' questionnaire results showed that students have a better understanding of the topic, work more actively in the classroom, and are more confident that they will complete the English lesson tasks if they acquire the subject's information before the class.

Difficulties are connected with providing a stable Internet connection and time-consuming preparation and planning process, but the once planned lesson is possible to use repeatedly.

Implementing the flipped learning approach is important because teachers need to teach using methods informed by the latest educational research and practice. New approach implementation requires teachers' professional development and observing the best practices.

\section{Acknowledgements}

The publication and presentation are made with the financial support of the project "Strengthen the academic staff of higher education institutions in the areas of strategic specialization at Liepaja University" No. 8.2.2.0/18/I/003.

\section{References}

Abdullah, M.Y., Hussin, S., \& Ismail, K. (2019). Implementation of Flipped Classroom Model and Its Effectiveness on English Speaking Performance. International Jornal of Emerging Technologies in Learning, 14(9), 130-147. doi.org/10.3991/ijet.v14i09.10348

Ansori, M., \& Nafi, N.N. (2018). English teachers perceived benefits and challenges of flipped classroom implementation. Journal of English Education and Linguistics Studies, 5(2), 211-227. doi.org/10.30762/jeels.v5i2.820

Bergmann, J., \& Sams, A. (2012). Flip Your Classroom Reach Every Student in Every Class Every Day ( $1^{\text {st }}$ ed). International Society for Technology in Education.

Bergmann, J., \& Sams, A. (2015). Flipped learning for Elementary Instruction (1st ed). International Society for Technology in Education.

Binit Halili, S.H., Hijja, N., Rabihah, N., Sulaiman, H., \& Razaket, R.A. (2019). Exploring the flipped classroom approach in the teaching and learning process: a case study of preservice teachers' views. International Jornal of Pedagogies and Learning, 14(1), 117. 10.1016/j.chb.2015.12.022

Flipped Learning Global Initiative. (n.d.). Flipped Learning Definition. Retrieved from https://flglobal.org/international_definition/ 
Girmen, P., \& Kaya, M.F. (2019). Using the Flipped Classroom Model in the Development of Basic Language Skills and Enriching Activities: Digital Stories and Games. International Journal of Instruction, 12(1), 555-572.

Gonzales, R.R. (2019). Flipped Classroom Approach: Experiences from a Philippine State University. The Normal Lights, Jornal of Teacher Education, 13(2), 67-89.

Jackson, N. (2019). Benefificial or Not: Flipped Learning in an Elementary Mathematics Classroom. Retrieved from https://digitalcommons.csumb.edu/caps_thes_all/641/

Kurnianto, B., Wiyanto, \& Haryani, S. (2020). Critical Thinking Skills and Learning Outcomes by Improving Motivation in the Model of Flipped Classroom. Journal of Primary Education, 9(3), 282-291. doi.org/10.15294/jpe.v9i3.27783

Lee, K., \& Lai, Y. (2017). Facilitating higher-order thinking with the flipped classroom model: a student teacher's experience in a Hong Kong secondary school. Research and Practice in Technology Enhanced Learning, 12(8), 1-14.

Marqués-Molías, L., Palau-Martín, R., Usart, M., \& Morilla, F. (2019). The Flipped classroom in the learning of korfball in fifth and sixth grade. Aloma, 37(2), 43-52.

McKenzie, L. (2018). Are You Flipping the Wrong Way? Retrieved from https://www.insidehighered.com/news/2018/03/27/group-seeks-set-standards-flippingclassroom

Ministry of Education and Science. (2020). Guidelines for the Development of Education for 2021-2027. Future Skills for the Future Society. Retrieved from https://www.izm.gov.lv/ lv/izglitibas-attistibas-pamatnostadnes-2021-2027gadam

Mohammadi, J., Barati, H., \&Youhanaee, M. (2019). The Effectiveness of Using Flipped Classroom Model on Iranian EFL Learners' English Achievements and Their Willingness to Communicate, English Language Teaching. Canadian Center of Science and Education, 12(5), 101.-115. doi:10.5539/elt.v12n5p101

Muntean, C.H. (2019). Teaching Tip: Flipping the Class to Engage Students in Learning Programming Algorithms. Society for Information Technology \& Teacher Education International Conference. 2019, 2320-2325.

Thomas, G. (2021). How to Do Your Case Study ( $3^{\text {rd }}$ ed). SAGE publications Ltd.

Tomas, L., Evans, N., Doyle, T., \& Skamp, K. (2019). Are first year students ready for a flipped classroom? A case for a flipped learning continuum. International Journal of Educational Technology in Higher Education, 16(5), 1-22. doi.org/10.1186/s41239-019-0135-4

Yean, L.S. (2019). Promoting active learning and independet learning among primary school students using flipped classroom. International Journal of Education, Psychology and Counseling, 4(30), 324-341.

Yoshida, H. (2019). Flipped learning for pre-service teacher education: with focus in instructional design for elementary and secondary education. 13th International Technology, Education and Development Conference, 5718-5727.

Youtube. (2018). Welcome 2 Unit 4. Retrieved from https://www.youtube.com/results? search_query=welcome+2+lesson+4

Zamora-Polo, F., Corrales-Serrano, P.M., Sánchez-Martín, J., \& Espejo-Antúnez, L. (2019). Nonscientific University Students Trainingin General Science Using an Active-Learning Merged Pedagogy: Gamification in a Flipped Classroom. MDPI Education Science, 9(297), 2-18. doi:10.3390/educsci9040297

Zou, D (2020). Gamified flipped EFL classroom for primary education: student and teacher perceptions. Journal of Computers in Education, 7(2), 213-228. doi.org/10.1007/s40692020-00153-w 